\title{
Pterygium and its relationship to the dry eye in the Bantu
}

\author{
LEON GOLDBERG AND ROBERT DAVID \\ From the Department of Ophthalmology, University of the Witwatersrand, and \\ Baragwanath Hospital, Fohannesburg, South Africa
}

The many diverse theories put forward to explain the pathogenesis of pterygia testify to the fact that their aetiology has as yet not been adequately explained. In recent years ultraviolet irradiation (Cameron, 1962; Elliot, 1966; Peckar, 1972) and microtrauma (Kubik, 1975) have been suggested as being major environmental predisposing factors. One theory is that tear film abnormalities cause local drying of the cornea and conjunctiva which in turn predisposes to these new growths (Barraquer, 1965; Elliot, 1966; Mackie, 1971 ; Greer, 1972; Paton, 1975). Elliot (1966) stated that the sequence was ultraviolet light causing drying and that this was followed by the pterygium. These theories have been supported by studies of geographical distribution (Cameron, 1962)-pterygia appearing to occur more frequently in hot, dry climates-and by clinical and biochemical studies of the tear film (Mackie, I97I). Our study was undertaken to investigate the correlation between the occurrence of pterygia and the 'dry eye'.

\section{Material and methods}

Both the patients with pterygia and the controls were drawn from Bantus living in Johannesburg, South Africa (latitude $26^{\circ} \mathrm{S}$ ), an industrial urban area with more than 250 sunny days a year. This area is within the latitudes $30^{\circ} \mathrm{N}$ and $\mathrm{S}$ where the incidence of pterygia is regarded as being highest (Cameron, 1962).

Forty-three patients with unilateral and eight with bilateral pterygia (59 eyes) and 23 normal subjects (46 eyes) aged between 44 and 79 years of both sexes were studied. The patients presented with one of three complaints: cosmetic, optical, or those due to secondary infection. No age or sex differences were found.

As the 'dry eye' is defined as being either a quantitative or qualitative dysfunction of the tear film (Dohlman, 1971), we submitted all our patients and controls to Schirmer's tests and fluorescein break up time tests. The Schirmer's test was used to determine the quantitative tear formation. $12 \mathrm{~mm}$ wetting or more on the $5 \times 30 \mathrm{~mm}$ strip of $\mathrm{N}^{\circ} 4 \mathrm{I}$ Whatman filter paper after five minutes was considered to be normal (Moses, 1970).

The fluorescein break up time test was used to measure the quality of the tear film (Girard and Moore,

Address for reprints: Dr Leon Goldberg, Department of Ophthalmology, University of Witwatersrand, Medical School, Hospital Street, Johannesburg 200I, South Africa
1969). A sterile Ayerst fluorescein strip was used and the tear film break up studied using the Cobalt light attachment of the Haag-Streit 900 slit-lamp. An intact tear film after 30 seconds was considered to be normal (Norn, 1969).

These tests were done when there was no clinical evidence of superimposed infection or other irritation which could predispose to excess tearing.

\section{Results}

The patients and controls were divided into two groups; those in whom the results of both Schirmer's and fluorescein break up time tests were normal and those in whom either or both tests were abnormal according to the above criteria (Table I).

Of the 59 eyes with pterygia, 19 showed normal tear film and 40 showed some abnormality, whereas in the 46 control eyes 15 were normal and 31 abnormal. These results were analysed statistically and the difference was shown to be of no significance $\left(\chi^{2}\right.$ with $\mathrm{I}^{\circ}$ of freedom $=0 ; \mathrm{P}$-not significant).

Twenty of the patients with unilateral pterygia had the results of these investigations on the affected eye compared with those of the fellow eye (Table II). This showed that eight of the eyes with pterygia and nine of the normal eyes had normal tear films. This was again not statistically significant $\left(\chi^{2}\right.$ with $\mathrm{I}^{\circ}$ of freedom $=0 ; \mathrm{P}-$ not significant).

\section{Discussion}

The finding of so many 'abnormal' results in both Schirmer's and fluorescein break up time tests in the trial groups and controls in spite of the fact

Table I Results of tests for patients and controls

\begin{tabular}{|c|c|c|}
\hline Test & Patients & Controls \\
\hline $\begin{array}{l}\text { Normal, Schirmer's } \\
\text { Normal, fluorescein break up time }\end{array}$ & 19 & 15 \\
\hline $\begin{array}{l}\text { Abnormal, Schirmer's } \\
\text { Normal, fluorescein break up time }\end{array}$ & 10 & I I \\
\hline $\begin{array}{l}\text { Abnormal, fluorescein break up time } \\
\text { Normal, Schirmer's }\end{array}$ & $9\} 40$ & $7\} 31$ \\
\hline $\begin{array}{l}\text { Abnormal, fluorescein break up time } \\
\text { Abnormal, Schirmer's }\end{array}$ & 21 & 13 \\
\hline
\end{tabular}




\section{Table II Patients with unilateral pterygia}

\begin{tabular}{|c|c|c|}
\hline Test & $\begin{array}{l}\text { Eye with } \\
\text { pterygium }\end{array}$ & $\begin{array}{l}\text { Unaffected } \\
\text { eye }\end{array}$ \\
\hline $\begin{array}{l}\text { Normal, Schirmer's } \\
\text { Normal, fluorescein break up time }\end{array}$ & 8 & 9 \\
\hline $\begin{array}{l}\text { Abnormal, Schirmer's } \\
\text { Normal, fluorescein break up time }\end{array}$ & 27 & $\mathbf{1}$ \\
\hline $\begin{array}{l}\text { Abnormal, fluorescein break up time } \\
\text { Normal, Schirmer's }\end{array}$ & $5\} 12$ & $3\}^{11}$ \\
\hline $\begin{array}{l}\text { Abnormal, fluorescein break up time } \\
\text { Abnormal, Schirmer's }\end{array}$ & 5 & 7 \\
\hline
\end{tabular}

that in none was there any symptom that could be related to 'dry eye', emphasized the present inadequacy of these gross tests. The Schirmer's test has been described by Wright (I97I) as being the 'only practical test of tear flow' but being 'of an unphysiological variety'.

This study has been one of many into the function of tears in the eyes of patients with pterygia. De Ocampo, Valenton, and Chavez (1969) could not show any relationship between the $\mathrm{pH}$ of the tears and incidence of pterygium in a population group in the Philippines. Our study using these gross tests, has failed to support the hypothesis of Mackie (197I) and Paton (1975) who support a primary tear film abnormality predisposing to pterygium formation.

If the mechanism of production of pterygia is initiated by ultraviolet light, as suggested by Elliot (1966), it has not been shown to be mediated by its effect on the tear film.

\section{Summary}

A comparative study was performed on two groups of Bantus in Johannesburg to see if there was any relationship between the 'dry eye' and pterygia, but no correlation was found.

\section{References}

BARRAQUER, J. I. (I965) Ophthalmologica (Basel), r50, I I I

Cameron, M. (1962) Trans. ophthal. Soc. Aust., 22, 67

De ocampo, G., valenton, M., and Chavez, J. G. (1969) Philipp. F. Ophthal., r, 77

DOHLMAN, C. H. (197I) Trans. ophthal. Soc. U.K., 91, 105

Elliot, R. (1966) Trans. ophthal. Soc. Aust., 25, 7 I

GIRARD, L. G., and MOORE, C. D. (I969) 'Proceedings of the First South African International Ophthalmology

Symposium', ed. M. H. Luntz, p. 25. Butterworth, London

GREER, C. H. (r972) 'Ocular Pathology', 2nd ed, pp. 96-97. Davis, Philadelphia

KUBIK, J. (1975) Ophthalmologica (Basel), 171, 18I

MACKIE, I. A. (197I) Trans. Ophthal. Soc. U.K., 91, 129

MOSES, R. A. (1970) 'Adler's Physiology of the Eye', 5th ed., p. 23. Mosby, St Louis

NORN, M. S. (1969) Acta ophthal. (Kbh.), 47, 865

Paton, D. (1975) Trans. Amer. Acad. Ophthal. Otolaryng., 79, 603

PECKAR, C. O. (1972) Docum. ophthal. (Den Haag), 31, I4I

WRIGHT, P. (I97I) Trans. ophthal. Soc. U.K., 9I, I I9 